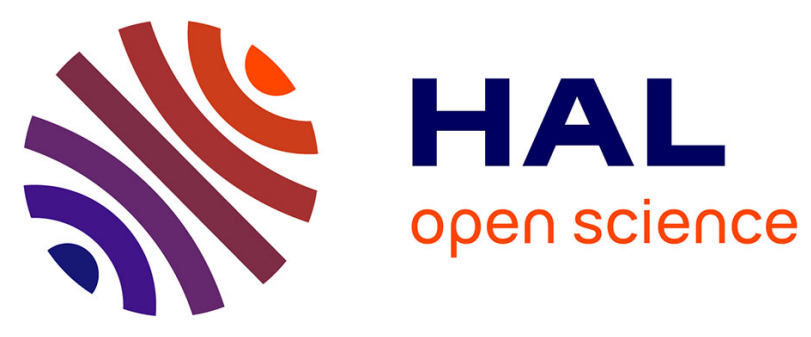

\title{
Pavement life cycle assessment - a comparison of American and European tools
}

Joao Miguel Santos, Senthilmurugan Thyagarajan, Elisabete Keijzer, Rocio Fernandez Flores, Gerardo Flintsch

\section{- To cite this version:}

Joao Miguel Santos, Senthilmurugan Thyagarajan, Elisabete Keijzer, Rocio Fernandez Flores, Gerardo Flintsch. Pavement life cycle assessment - a comparison of American and European tools. Pavement Life-Cycle Assessment Symposium 2017, Apr 2017, CHAMPAIGN, United States. hal-01651650

\section{HAL Id: hal-01651650 https://hal.science/hal-01651650}

Submitted on 29 Nov 2017

HAL is a multi-disciplinary open access archive for the deposit and dissemination of scientific research documents, whether they are published or not. The documents may come from teaching and research institutions in France or abroad, or from public or private research centers.
L'archive ouverte pluridisciplinaire HAL, est destinée au dépôt et à la diffusion de documents scientifiques de niveau recherche, publiés ou non, émanant des établissements d'enseignement et de recherche français ou étrangers, des laboratoires publics ou privés. 


\title{
Pavement life cycle assessment: a comparison of American and European tools
}

\author{
J. Santos \\ IFSTTAR, AME-EASE, Bouguenais, France
}

S. Thyagarajan

Turner Fairbank Highway Research Center, VA, USA

E. Keijzer

TNO, Utrecht, The Netherlands

R. Flores

ACCIONA S.A. Corporate Division. Sustainability and CSR Area, Madrid, Spain

G. Flintsch

ABSTRACT: Road pavements have considerable environmental burdens associated with their initial construction, maintenance and usage. This fact has led the pavement stakeholder community make congregate efforts to better understand and mitigate these negative effects. Life cycle assessment (LCA) is a versatile methodology adopted to quantify the effect of decisions regarding the selection of resources and processes. However, there is a considerable variety of tools for conducting pavement LCAs. The objective of this paper is to provide the pavement stakeholder community with insights on the potential differences in the life cycle impact assessment results of a pavement by applying American and European LCA tools, namely PaLATE V2.2, VTTI/UC asphalt pavement LCA model, GaBi, DuboCalc and ECORCE-M, to a Spanish pavement reconstruction project. Construction and maintenance life cycle stages were considered in the comparison. Based on the impact assessment methods adopted by the different tools, the following indicators and impact categories were analyzed: energy consumption, climate change, acidification, eutrophication and photochemical ozone creation. The results of the case study showed that it is of pivotal importance to develop (1) a more standardized framework for performing a LCA of road pavement that can be adapted to various tools and (2) local databases of materials and processes, which follow national and international standards.

\section{INTRODUCTION}

Road pavements have considerable environmental burdens associated with their construction, maintenance, and use. Concurrently, the environmental issues are becoming more relevant in social and political contexts. This has led the pavement stakeholder community to congregate efforts to better understand and mitigate these negative effects.

A "twining" activity was initiated in 2014 between the LCE4ROADS consortium (FP7 European Union- funded project Grant Agreement $\mathrm{n}^{\circ}$ 605748), led by ACCIONA, and the U.S. National Sustainable Pavements Consortium pooled fund effort, led by the Virginia Department of Transportation (VDOT), supported by the U.S. Federal Highway Administration (FHWA) and three other State Departments of Transportation (DOTs), and managed by the Virginia Tech Transportation Institute (VTTI). This cooperative initiative resulted from an arrangement signed in Washington on February 12, 2013, by the European Commission (EC) and the U.S. DOT that aims to foster collaboration on research, development, and technology transfer activities that are of mutual benefit. In particular, the main objective of this twining activity is to foster the exchange of knowledge across the Atlantic, finding synergies in research aimed at enhancing sustainability in pavements. The agreement focuses on the following aspects: (1) life cycle assessment (LCA) methodologies and their applications to roads pavement construction and maintenance practices; (2) life cycle cost analysis (LCCA) for pavements and integration of use phase models, including analysis of the influence of pavement deterioration on vehicle fuel con- 
sumption and emissions and the interaction between pavement, environment, and humans; (3) climate change (CC) adaptation measures for road infrastructures; (4) Product Category Rules (PCRs) and Environmental Product Declarations (EPDs); and (5) implementation of strategies in terms of Green Public Procurement for road infrastructures.

To improve the sustainability of road pavement infrastructure, road agencies and construction companies are adopting appropriate methodologies and tools to identify priority areas for improvement. Thus, it is necessary to know the impact of pavements on the environment to develop and implement approaches and procedures that can produce the greatest gains in all aspects and dimensions of the system. LCA is a versatile methodology capable of informing decisions on resource and process selection to better understand, measure, and reduce the environmental impacts of a system Glass et al. (2013).

However, there is a considerable variety of tools for conducting pavement LCA, and there are notable differences between them. Available tools cover different phases and processes of the pavement's life cycle, take different environmental issues into account, and model with distinct levels of accuracy within chosen functional units and system boundaries. They can be global, national, or even regional or local. They have also been developed for different purposes, (e.g., research, consulting, and decision making), and their domain of applicability is tailored for different phases of a project's life cycle, (e.g., planning, designing, construction and maintenance). Furthermore, they use different foreground and background generic or industry data. Also distinct is the level of interaction they allow with the user. While some of the tools are "blackboxes" in the sense that only the default processes and data can be used, others allow users to use their own data, to choose the database that best match the features of the case study, or even to modify the existing datasets.

\section{BACKGROUND}

Over the last few years, many LCA tools have been developed for assisting decision makers in evaluating the environmental performance of their pavement-related decisions. The set of pavement-specific LCA tools includes, among others, PaLATE V2.2 (PaLATE V2.2 2011), UK asphalt pavement LCA model (Huang et al. 2009), PE-2 (Mukherjee \& Cass 2012), ECORCEM (Dauvergne et al. 2014), DuboCalc (Rijkswaterstaat 2015), $\mathrm{CO}_{2}$ NSTRUCT (FernándezSánchez et al. 2015), VTTI/UC asphalt pavement LCA model (Santos et al. 2015a,b) and Athena Impact Estimator for Highways (ASMI 2012). Commercial LCA tools, such as SimaPro (PRé Consultants 2016) and GaBi (PE International 2012), despite being not specifically designed for pavement-specific LCAs, have been used for that purpose (Blankendaal et al. 2014) since they are quite complete in terms of the elementary flows inventoried and unit processes taken into account, some of which are particularly applicable to the pavement domain (e.g., raw materials and equipment fuel combustion).

Moreover, LCA is a data-intensive method and thus the LCA tools are provided with databases which commonly present distinctive features in terms of data sources, elementary flows inventoried and unit processes taken into account, technical, temporal and geographical representativeness. For further information on the impacts of using different databases on the final results of infrastructure LCA studies the reader is referred to (Takano et al. 2014).

\section{OBJECTIVES}

The main objective of this paper is to provide the pavement stakeholder community with insights on the potential differences in the life cycle impact assessment (LCIA) results of a pavement LCA by applying American and European LCA tools to a Spanish case study. As a consequence of comparing the features of different tools and potential life cycle environmental impacts, the differences in datasets and life cycle inventory will be analyzed as well. In order to avoid an excessive level of complexity, the number of tools considered in the study had to be controlled. The tools selected were: (1) PaLATE V2.2, (2) VTTI/UC asphalt pavement LCA model, (3) GaBi; (4) DuboCalc and, (5) ECORCE-M. 


\section{OVERVIEW OF THE TOOLS COMPARED}

An overview of the features of each tool is given in Table 1.

Table 1. Overview of the different LCA tools.

\begin{tabular}{|c|c|c|c|c|c|}
\hline Feature & $\mathrm{GaBi}$ & PaLATE V2.2 & DuboCalc & VTTI/UC & $\begin{array}{l}\text { ECORCE- } \\
\text { M }\end{array}$ \\
\hline Country & Germany & USA & Netherlands & USA & France \\
\hline $\begin{array}{l}\text { Primary } \\
\text { data } \\
\text { source }\end{array}$ & $\begin{array}{l}\text { Literature and indus- } \\
\text { trial data; other data- } \\
\text { bases (US LCI, } \\
\text { ELCD, ecoinvent, } \\
\text { etc.) }\end{array}$ & $\begin{array}{l}\text { Carnegie Mellon } \\
\text { University EIO-LCA } \\
\text { software; Transporta- } \\
\text { tion Energy Data } \\
\text { Book }\end{array}$ & $\begin{array}{l}\text { National da- } \\
\text { ta }\end{array}$ & $\begin{array}{l}\text { Literature } \\
\text { data }\end{array}$ & $\begin{array}{l}\text { Literature } \\
\text { and indus- } \\
\text { trial data }\end{array}$ \\
\hline $\mathrm{AD}$ & $-*$ & - & $\mathrm{Y}$ & - & - \\
\hline CC & $\mathrm{Y}$ & $\mathrm{Y}$ & $\mathrm{Y}$ & $\mathrm{Y}$ & $\mathrm{Y}$ \\
\hline OD & $\mathrm{Y}$ & - & $\mathrm{Y}$ & - & - \\
\hline POC & $\mathrm{Y}$ & - & $\mathrm{Y}$ & $\mathrm{Y}$ & $\mathrm{Y}$ \\
\hline AC & $\mathrm{Y}$ & - & $\mathrm{Y}$ & $\mathrm{Y}$ & $\mathrm{Y}$ \\
\hline$\stackrel{d}{\uplus} \mathrm{EU}$ & $\mathrm{Y}$ & - & $\mathrm{Y}$ & $\mathrm{Y}$ & $\mathrm{Y}$ \\
\hline త $\mathrm{HT}$ & $\mathrm{Y}$ & - & $\mathrm{Y}$ & - & - \\
\hline ت્ّ $\mathrm{FAE}$ & $\mathrm{Y}$ & - & $\mathrm{Y}$ & - & - \\
\hline 互 MAE & $\mathrm{Y}$ & - & $\mathrm{Y}$ & - & - \\
\hline $\mathrm{TE}$ & $\mathrm{Y}$ & - & $\mathrm{Y}$ & - & - \\
\hline $\mathrm{EC}$ & $\mathrm{Y}$ & $\mathrm{Y}$ & - & $\mathrm{Y}$ & $\mathrm{Y}$ \\
\hline НHCР & - & - & - & $\mathrm{Y}$ & - \\
\hline CE & - & - & - & - & $\mathrm{Y}^{* *}$ \\
\hline CT & - & - & - & - & $\mathrm{Y}$ \\
\hline
\end{tabular}

Legend: AD- abiotic depletion; CC- climate change; OD- ozone depletion; POC- photochemical ozone creation; AC- acidification; EU- eutrophication; HT- human toxicity; FAE- freshwater aquatic ecotoxicity; MAE- marine aquatic ecotoxicity; TE- terrestrial ecotoxicity; EC- energy consumption; HHCP- Human health criteria pollutants; CE- chronic ecotoxicity; CT- chronic toxicity; Notes: * "-“means impact category not measured; ** Beyond the toxicity specific to humans, which has been treated separately in ECORCE-M (chronic toxicity), all other toxicity indicators for the various ecosystems (i.e., freshwater aquatic, marine aquatic and terrestrial) have been aggregated into this single ecotoxicity indicator.

\section{METHODOLOGY}

\subsection{Goal and scope definition}

This paper presents and compares the results of an LCA of a pavement reconstruction project on a Spanish road section, N-340, located in Elche (Alicante), performed through the application of several LCA tools.

\subsection{Functional unit}

The function of the product system is to provide safe, comfortable, economical, and durable driving conditions over the project analysis period. The functional unit considered as a reference basis is the quantified function provided by the product system. In this case study, it is defined as $1 \mathrm{~km}$ of mainline pavement and year. The analysis period is 20 years and comprises the maintenance of the top pavement structure layer at year 10. The assessed road section is 1,568 $\mathrm{m}$ long and has four lanes, divided into two roadways separated by a central separator. The inputs (raw materials and energy consumption) were collected and quantified from the ACCIONA work site in 2012. 


\subsection{System boundaries and general assumptions}

The N-340 road received an EPD in December 2013 (Fernandez 2013). EPD is an Eco-label type III that aims to communicate transparently the environmental performance of a product, process, or system. It follows the rules established both in the International Organization for Standardization (ISO) 14025 (ISO 2006) and in the PCR guideline. In this project, the PCR named "highways, streets and roads" (EPD 2013) was used.

To compare the different LCA tools in a fair way, only the pavement life cycle phases and sub-phases that can be assessed with all five LCA tools were included in the analysis: (1) materials extraction and production, (2) transportation of materials, and (3) construction and maintenance and rehabilitation (M\&R). The environmental impacts related to the usage phase and the traffic disruption caused by the performance of M\&R activity were not assessed because not all of the tools evaluated in this study are capable of assessing these phases. Finally, the EOL was not taken into account because of its negligible contribution to the environmental life cycle impacts $(<1 \%)$ (EPD 2013). As far as the materials extraction and production phase is concerned, it must be noted that at least 99\% of material and energy requirements during the pavement life cycle were considered. The construction stages accounted for in this study are as follows: (1) demolition of the old pavement and fence; (2) soil excavation and movement; (3) pavement structure construction; (4) road sub-structure construction (e.g., drainage system); (5) M\&R of the top layer.

Other stages, such as the production of traffic control devices (for signposting and for diverting traffic) and the construction of tunnels and bridges, were not included in the analysis due to their residual existence in this specific case study. When modeling the transportation of materials phase, an average distance of $20 \mathrm{~km}$ was considered for all concrete-based materials as there is a concrete plant near the road. For the borrowed soil and aggregates/gravel materials, an average distance of $15 \mathrm{~km}$ was assumed. With regard to the transportation of the soil removed from the work site, a 3-km long hauling movement was adopted.

Finally, the environmental impacts stemming from the construction of the infrastructure associated with intermodal activities, the operation of vehicles for loading and uploading at terminals, the production of manufacturing equipment and personnel activities were also disregarded.

\section{LIFE CYCLE INVENTORY}

The LCI stage of an LCA aims to identify and quantify the environmentally significant inputs, such as material and energy, and outputs, such as air emissions, water effluents and solid waste disposal, of a system by means of mass and energy balances. The elementary output flows were inventoried according to the methodology of each tool and the databases that feed them. Table 2 summarizes the type of materials applied in each construction stage considered in the case study. Because the tools have different ways of modeling the energy consumption, it was converted and expressed in terms of electricity.

Table 2. Input materials as modeled in different tools.

\begin{tabular}{|c|c|c|c|c|c|c|c|}
\hline Stage & Baseline* & Quantity & DuboCalc & ECORCE-M & $\mathrm{GaBi}$ & PaLATE V2.2 & VTTI/UC \\
\hline 1 & $\begin{array}{l}\text { total ener- } \\
\text { gy con- } \\
\text { sumption }\end{array}$ & $\begin{array}{l}32779 \\
\text { kWh }\end{array}$ & $\begin{array}{l}\text { grey elec- } \\
\text { tricity, NL }\end{array}$ & $\begin{array}{l}\text { energy consump- } \\
\text { tion of construction } \\
\text { equipment \& haul- } \\
\text { ing trucks }\end{array}$ & $\begin{array}{l}\text { electricity } \\
\text { grid mix } \\
\text { (ES) }\end{array}$ & $\begin{array}{l}\text { default construction } \\
\& \text { transportation } \\
\text { equipment }\end{array}$ & $\begin{array}{l}\text { US diesel for } \\
\text { non-road en- } \\
\text { gines }\end{array}$ \\
\hline \multirow{4}{*}{2} & $\begin{array}{l}\text { total ener- } \\
\text { gy con- } \\
\text { sumption }\end{array}$ & $\begin{array}{l}250686 \\
\text { kWh }\end{array}$ & $\begin{array}{l}\text { included in } \\
\text { soil pro- } \\
\text { cessing da- } \\
\text { ta }\end{array}$ & $\begin{array}{l}\text { energy consump- } \\
\text { tion of construction } \\
\text { equipment \& haul- } \\
\text { ing trucks }\end{array}$ & $\begin{array}{l}\text { electricity } \\
\text { grid mix } \\
\text { (ES) }\end{array}$ & $\begin{array}{l}\text { default construction } \\
\& \text { transportation } \\
\text { equipment }\end{array}$ & $\begin{array}{l}\text { US diesel for } \\
\text { non-road en- } \\
\text { gines }\end{array}$ \\
\hline & $\begin{array}{l}\text { general fill } \\
\text { (soil) }\end{array}$ & $1797 \mathrm{~m}^{3}$ & $\begin{array}{l}\text { soil move- } \\
\text { ment (3 } \\
\mathrm{km})\end{array}$ & $-* *$ & $\begin{array}{l}\text { gravel, } \\
\text { grain size } \\
2 / 32\end{array}$ & $\begin{array}{l}\text { accounts for soil, } \\
\text { impact similar to } \\
\text { aggregate }\end{array}$ & - \\
\hline & water & $627 \mathrm{~m}^{3}$ & - & $\begin{array}{l}\text { water (no envi- } \\
\text { ronmental impacts) }\end{array}$ & water & water & tap water \\
\hline & $\begin{array}{l}\text { selected } \\
\text { material }\end{array}$ & $13256 \mathrm{~m}^{3}$ & $\begin{array}{l}\text { soil move- } \\
\text { ment ( } 3\end{array}$ & - & $\begin{array}{l}\text { gravel, } \\
\text { grain size }\end{array}$ & $\begin{array}{l}\text { accounts for soil, } \\
\text { impact similar to }\end{array}$ & - \\
\hline
\end{tabular}


Table 3. Input materials as modeled in different tools (continued).

\begin{tabular}{|c|c|c|c|c|c|c|c|}
\hline Stage & Baseline* & Quantity & DuboCalc & ECORCE-M & $\mathrm{GaBi}$ & PaLATE V2.2 & VTTI/UC \\
\hline \multirow{10}{*}{3} & $\begin{array}{l}\text { total ener- } \\
\text { gy con- } \\
\text { sumption }\end{array}$ & $\begin{array}{l}415021 \\
\text { kWh }\end{array}$ & $\begin{array}{l}\text { included in } \\
\text { soil pro- } \\
\text { cessing da- } \\
\text { ta }\end{array}$ & $\begin{array}{l}\text { energy consump- } \\
\text { tion of construction } \\
\text { equipment \& haul- } \\
\text { ing trucks }\end{array}$ & $\begin{array}{l}\text { electricity } \\
\text { grid mix } \\
(\mathrm{ES})\end{array}$ & $\begin{array}{l}\text { default construc- } \\
\text { tion \& transpor- } \\
\text { tation equipment }\end{array}$ & $\begin{array}{l}\text { US diesel for } \\
\text { non-road en- } \\
\text { gines }\end{array}$ \\
\hline & $\begin{array}{l}\text { soil from } \\
\text { borrowed } \\
\text { site }\end{array}$ & $398 \mathrm{~m}^{3}$ & $\begin{array}{l}\text { soil from } \\
\text { local pro- } \\
\text { ject (15 } \\
\mathrm{km})\end{array}$ & - & $\begin{array}{l}\text { gravel, } \\
\text { grain size } \\
2 / 32\end{array}$ & $\begin{array}{l}\text { accounts for soil, } \\
\text { impact similar to } \\
\text { aggregate }\end{array}$ & - \\
\hline & water & $124 \mathrm{~m}^{3}$ & - & $\begin{array}{l}\text { water (no envi- } \\
\text { ronmental impacts) }\end{array}$ & water & water & tap water \\
\hline & $\begin{array}{l}\text { graded } \\
\text { aggregates }\end{array}$ & $3187 \mathrm{~m}^{3}$ & $\begin{array}{l}\text { gravel from } \\
\text { rivers (15 } \\
\mathrm{km})\end{array}$ & $\begin{array}{l}\text { aggregates, in } \\
\text { quarry }\end{array}$ & $\begin{array}{l}\text { limestone, } \\
\text { crushed } \\
\text { gravel, } \\
\text { grain size } \\
2 / 16\end{array}$ & $\begin{array}{l}\text { graded aggre- } \\
\text { gates }\end{array}$ & $\begin{array}{l}\text { limestone; } \\
\text { quartzite }\end{array}$ \\
\hline & $\begin{array}{l}\text { bitumen } \\
\text { emulsion }\end{array}$ & $24 \mathrm{t}$ & $\begin{array}{l}\text { bituminous } \\
\text { emulsion }\end{array}$ & $\begin{array}{l}\text { bituminous emul- } \\
\text { sion }\end{array}$ & $\begin{array}{l}\text { bitumen } \\
\text { emulsion }\end{array}$ & $\begin{array}{l}\text { bitumen emul- } \\
\text { sion; does not } \\
\text { differentiate } \\
\text { emulsion \& PG } \\
\text { bitumen }\end{array}$ & $\begin{array}{l}\text { bitumen emul- } \\
\text { sion } 65 \%\end{array}$ \\
\hline & $\begin{array}{l}\text { asphalt } \\
\text { concrete } \\
\text { AC } 32 \\
\text { Base G }\end{array}$ & $5395 \mathrm{t}$ & $\begin{array}{l}\text { stone mas- } \\
\text { tic asphalt, } \\
0 \% \text { recy- } \\
\text { cled con- } \\
\text { tent }\end{array}$ & $\begin{array}{l}\text { hot asphalt mixes, } \\
\text { in gas plant }\end{array}$ & $\begin{array}{l}\text { asphalt } \\
\text { supporting } \\
\text { layer }\end{array}$ & $\begin{array}{l}\text { modeled as indi- } \\
\text { vidual materials }\end{array}$ & $\begin{array}{l}\text { asphalt concrete } \\
\text { AC } 32 \text { Base G }\end{array}$ \\
\hline & $\begin{array}{l}\text { asphalt } \\
\text { concrete } \\
\text { AC } 22 \text { Bin } \\
\text { S }\end{array}$ & $2324 t$ & $\begin{array}{l}\text { AC Surf, } \\
\text { dense as- } \\
\text { phalt con- } \\
\text { crete }\end{array}$ & $\begin{array}{l}\text { hot asphalt mixes, } \\
\text { in gas plant }\end{array}$ & $\begin{array}{l}\text { asphalt } \\
\text { pavement }\end{array}$ & $\begin{array}{l}\text { modeled as indi- } \\
\text { vidual materials }\end{array}$ & $\begin{array}{l}\text { asphalt concrete } \\
\text { AC } 22 \text { Bin S }\end{array}$ \\
\hline & $\begin{array}{l}\text { penetra- } \\
\text { tion grade } \\
(\mathrm{PG}) \text { bi- } \\
\text { tumen }\end{array}$ & $320 t$ & $\begin{array}{l}\text { bituminous } \\
\text { emulsion } \\
\text { (proxy) }\end{array}$ & $\begin{array}{l}\text { bitumen, } 20 \text { to } 220 \\
\text { grade }\end{array}$ & $\begin{array}{l}\text { bitumen } \\
\text { (grade) }\end{array}$ & $\begin{array}{l}\text { PG bitumen; } \\
\text { does not differ- } \\
\text { entiate emulsion } \\
\text { \& PG bitumen }\end{array}$ & PG 70-22 binder \\
\hline & $\begin{array}{l}\text { concrete } \\
\text { (brick) }\end{array}$ & $310 \mathrm{~m}^{3}$ & $\begin{array}{l}\text { concrete } \\
\text { C20/25 } \\
\text { (CEM I) }\end{array}$ & $\begin{array}{l}\text { concrete, at mixing } \\
\text { plant }\end{array}$ & $\begin{array}{l}\text { concrete } \\
\text { (stones, } \\
\text { bricks) }\end{array}$ & $\begin{array}{l}\text { modeled as indi- } \\
\text { vidual materials }\end{array}$ & concrete (brick) \\
\hline & $\begin{array}{l}\text { glass fi- } \\
\text { bers fila- } \\
\text { ments }\end{array}$ & $92 \mathrm{~m}^{3}$ & $\begin{array}{l}\text { plastic fi- } \\
\text { bers (sub } \\
\text { process } \\
\text { from "fiber } \\
\text { reinforced } \\
\text { concrete") }\end{array}$ & - & $\begin{array}{l}\text { glass fibers } \\
\text { mesh }\end{array}$ & $\begin{array}{l}\text { glass fibers fila- } \\
\text { ments }\end{array}$ & - \\
\hline
\end{tabular}


Table 4. Input materials as modeled in different tools (continued).

\begin{tabular}{|c|c|c|c|c|c|c|c|}
\hline Stage & Baseline* & Quantity & DuboCalc & ECORCE-M & $\mathrm{GaBi}$ & PaLATE V2.2 & VTTI/UC \\
\hline \multirow{5}{*}{4} & $\begin{array}{l}\text { total ener- } \\
\text { gy con- } \\
\text { sumption }\end{array}$ & $\begin{array}{l}3820 \\
\text { kWh }\end{array}$ & $\begin{array}{l}\text { included in } \\
\text { soil pro- } \\
\text { cessing da- } \\
\text { ta }\end{array}$ & $\begin{array}{l}\text { energy consump- } \\
\text { tion of construction } \\
\text { equipment \& haul- } \\
\text { ing trucks }\end{array}$ & $\begin{array}{l}\text { electricity } \\
\text { grid mix } \\
\text { (ES) }\end{array}$ & $\begin{array}{l}\text { default construc- } \\
\text { tion \& transpor- } \\
\text { tation equipment; }\end{array}$ & $\begin{array}{l}\text { US diesel for } \\
\text { non-road en- } \\
\text { gines }\end{array}$ \\
\hline & $\begin{array}{l}\text { concrete } \\
\text { C20 }\end{array}$ & $510 \mathrm{~m}^{3}$ & $\begin{array}{l}\text { concrete } \\
\text { C20/25 } \\
(\mathrm{CEM} \mathrm{I)} \\
\end{array}$ & $\begin{array}{l}\text { concrete, at mixing } \\
\text { plant }\end{array}$ & $\begin{array}{l}\text { concrete } \\
\text { C20/25 }\end{array}$ & $\begin{array}{l}\text { modeled as indi- } \\
\text { vidual materials }\end{array}$ & concrete HM20 \\
\hline & soil & $\begin{array}{l}200893 \\
\mathrm{~m}^{3}\end{array}$ & $\begin{array}{l}\text { soil move- } \\
\text { ment ( } 3 \\
\mathrm{~km})\end{array}$ & - & gravel & $\begin{array}{l}\text { accounts for soil, } \\
\text { impact similar to } \\
\text { aggregate }\end{array}$ & - \\
\hline & formwork & $0.04 \mathrm{~m}^{3}$ & $\begin{array}{l}\text { traditional } \\
\text { formwork } \\
\text { (converted } \\
\left.\text { to } \mathrm{m}^{2}\right) \\
\end{array}$ & - & $\begin{array}{l}\text { laminated } \\
\text { wood }\end{array}$ & - & - \\
\hline & $\begin{array}{l}\text { concrete } \\
\text { C15 }\end{array}$ & $41 \mathrm{~m}^{3}$ & $\begin{array}{l}\text { concrete } \\
\text { C12/15 } \\
(\mathrm{CEM} \mathrm{I)} \\
\end{array}$ & $\begin{array}{l}\text { concrete, at mixing } \\
\text { plant }\end{array}$ & $\begin{array}{l}\text { concrete } \\
\text { C12/15 }\end{array}$ & $\begin{array}{l}\text { modeled as indi- } \\
\text { vidual materials }\end{array}$ & concrete HM15 \\
\hline \multirow{3}{*}{5} & $\begin{array}{l}\text { total ener- } \\
\text { gy con- } \\
\text { sumption }\end{array}$ & $\begin{array}{l}106562 \\
\text { kWh }\end{array}$ & $\begin{array}{l}\text { included in } \\
\text { soil pro- } \\
\text { cessing da- } \\
\text { ta }\end{array}$ & $\begin{array}{l}\text { energy consump- } \\
\text { tion of construction } \\
\text { equipment \& haul- } \\
\text { ing trucks }\end{array}$ & $\begin{array}{l}\text { Electricity } \\
\text { grid mix } \\
\text { (ES) }\end{array}$ & $\begin{array}{l}\text { default construc- } \\
\text { tion \& transpor- } \\
\text { tation equipment; } \\
\text { specific details } \\
\text { not available }\end{array}$ & $\begin{array}{l}\text { US diesel for } \\
\text { non-road en- } \\
\text { gines }\end{array}$ \\
\hline & $\begin{array}{l}\text { asphalt } \\
\text { concrete } \\
\text { AC } 22 \text { Bin } \\
\text { S }\end{array}$ & $2324 t$ & $\begin{array}{l}\text { AC Surf, } \\
\text { dense as- } \\
\text { phalt con- } \\
\text { crete }\end{array}$ & $\begin{array}{l}\text { hot asphalt mixes, } \\
\text { in gas plant }\end{array}$ & $\begin{array}{l}\text { asphalt } \\
\text { pavement }\end{array}$ & $\begin{array}{l}\text { modeled as indi- } \\
\text { vidual materials }\end{array}$ & $\begin{array}{l}\text { asphalt concrete } \\
\text { AC } 22 \text { Bin S }\end{array}$ \\
\hline & prime coat & $13 \mathrm{t}$ & $\begin{array}{l}\text { bituminous } \\
\text { emulsion } \\
\text { (proxy) }\end{array}$ & $\begin{array}{l}\text { bituminous emul- } \\
\text { sion }\end{array}$ & $\begin{array}{l}\text { asphalt } \\
\text { binder }\end{array}$ & $\begin{array}{l}\text { prime coat; does } \\
\text { not differentiate } \\
\text { emulsion \& PG } \\
\text { bitumen }\end{array}$ & $\begin{array}{l}\text { prime coat (bi- } \\
\text { tuminous emul- } \\
\text { sion) }\end{array}$ \\
\hline
\end{tabular}

* The "baseline” was the starting point of all tools; ** “-” means that this process was not available in the specific tool and was excluded in calculations.

\section{LIFE CYCLE IMPACT ASSESSMENT}

In the LCIA stage of an LCA, the LCI results are assigned to different impact categories based on the expected types of impacts on the environment. In this study the Center for Environmental Studies of the University of Leiden's “CML 2001" impact assessment method (Guinée 2002) is implemented by several tools, either in a direct way (i.e., $\mathrm{GaBi}$ ) or by adapting the original indicators (i.e., ECORCE-M and DuboCalc). Alternatively, the VTTI/UC pavement LCA tool adopts the Tool for the Reduction and Assessment of Chemical and other environmental Impacts 2.0 (TRACI 2.0) method (Bare 2011). In the case of PaLATE V2.2 only the CC impact category is considered, taking the $\mathrm{CO}_{2}$ emissions exclusively into account. The LCIA indicators were calculated at the mid-point level from (1) resource consumption flows, e.g., energy, (2) air emission flows, e.g., the 100-year horizon CC, etc., and (3) air, soil, and water pollutant flows, i.e. toxicity indicators. 


\section{RESULTS AND DISCUSSION}

\subsection{Impacts on a material level}

Figure 1 shows the potential environmental impacts of the materials used in this case study, per kilogram of material, and calculated by the different tools. All axes are cut-off and the scores greater than the cut-off threshold are displayed in boxes. On x-axis, the percentages (\%) next to each material show the coefficient of variation (CV) of the values per material in each impact category. Furthermore, because not all tools cover the same impact categories (as shown in Table 1), the graphs present only the results obtained with the tools which are able to consider the impact category under evaluation. At first glance, it is clear that the impacts per kilogram of material differ largely among the tools for some of the materials, while other materials have rather comparable impacts. Taking the CC impact category as an example, Figure 1a shows that the CV values range approximately from 32 to $121 \%$. Water and concrete C20 present the highest variability (121\% and $112 \%$, respectively). Cement, concrete brick, and concrete C15 also exhibit high CV values (86 to 111\%), though the LCIs associated with these materials are well defined and quantified by researchers for many years. On the contrary, asphalt concrete, bitumen and bitumen emulsion denote the lowest variability (30 to 60\%). In general, the scores for the remaining materials have a much lower impact than the materials that present high levels of variability. One can conclude that the generality of the most common and bulk materials are well researched and represented by the tools, while the LCIs of more specific materials like water, formwork and glass fibers are more difficult to quantify in accurate fashion, and, thus, have been disregarded by several tools or based on proxy elements.

When comparing the $\mathrm{CV}$ values of the same material across the several impact categories, the CC impact category was found to exhibit the lowest levels of variability for the generality of the materials. This result is explained by the fact that all the LCIA methods adopted by the tool use the characterization factors based on the Intergovernmental Panel on Climate Change model. On the other hand, the energy consumption indicator generates the highest CV values. To a great extent this outcome can be explained by the fact that the impact category scores calculated with the $\mathrm{GaBi}$ tool are extremely high for the majority of the materials in comparison to the scores calculated with the other tools. Such a result suggests that $\mathrm{GaBi}$ might have other definitions for these materials or consider different system boundaries, which might influence the conclusions drawn on this case study. Furthermore, this discrepancy also illustrates the importance of using consistent sources and local databases as different materials may have different sources or may be produced using different processes with significantly different environmental loads. For example, different form materials may be used in different regions.

\subsection{Life cycle impact assessment comparison}

Figure 2 presents the environmental impacts associated with each construction stage considered in the case study (represented in log-scale) and the relative contributions to the total score on various impact categories that are computed by the majority of the LCA tools. In general, considerable variation was observed within each impact category computed by the different LCA tools. The GaBi tool was found to yield the lowest impact scores when compared with the other evaluated tools. Interestingly, the POC scores associated with stages 1 and 2 possess a negative value. This result indicates that in these stages there is a mitigation effect on the POC impact category. To the contrary, PaLATE V2.2 was found to produce the highest scores for the two impact categories that it is able to account for (i.e., CC and energy consumption). The only exception to this general trend was observed in the case of the energy consumed during stage 3. The VTTI/UC and ECORCE-M tools denoted similar CC and energy consumption scores. This result contrasts with those observed for the remaining impact categories, as they were found to vary considerably. Also, the scores obtained with VTTI/UC and ECORCE-M tools were higher than those generated by $\mathrm{GaBi}$ for all impact categories. The DuboCalc tool produced intermediate scores relative to those generated by $\mathrm{GaBi}$ and VTTI/UC for the CC and energy consumption indicators. However, the AC, EU, and POC scores computed by DuboCalc for stages 3, 4, and 5 were the highest among those calculated by all the compared tools.

Regarding the relative contributions of each construction stage to the total scores, Figure 2 (right) shows that construction stage 1 is the smallest contributor for each impact category, re- 
gardless of the LCA tool considered. Construction stage 3 was found to be the main contributor. The only exception to this uniform outcome was obtained with PaLATE V2.2. As explained before, the quantity of soil used in stage 4 combined with the LCA approach adopted by PaLATE V2.2 led to a higher relative contribution from this stage in both CC and energy consumption indicators. 

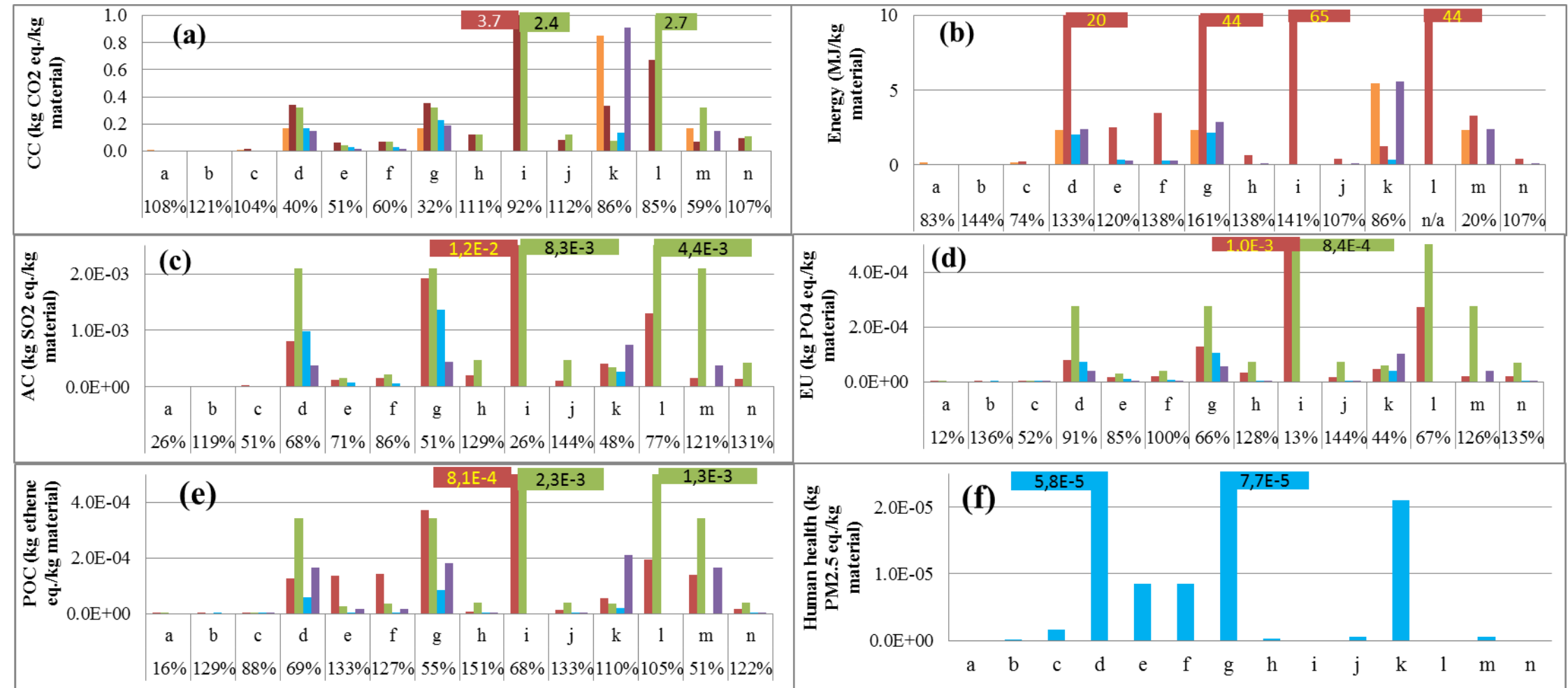

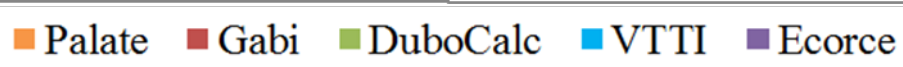

$\begin{array}{ll}\text { a. General fill (soil) } & \text { h. Concrete (brick) } \\ \begin{array}{ll}\text { b. Water } & \text { i. Glass fibres filaments } \\ \text { c. Graded aggregates } & \text { j. Concrete C20 } \\ \text { d. Bitumen Emulsion } & \text { k. Cement } \\ \text { e. AC } 32 \text { Base G } & \text { I. Formwork } \\ \text { f. AC } 22 \text { Bin S } & \text { m. Prime coat } \\ \text { g. PG bitumen } & \text { n. Concrete C15 }\end{array}\end{array}$

Figure 1. Environmental impacts per kilogram of product, calculated with the five different tools for six environmental impact categories (a) CC; (b) energy consumption; (c) AC; (d) EU, (e) POC and (f) human health. 


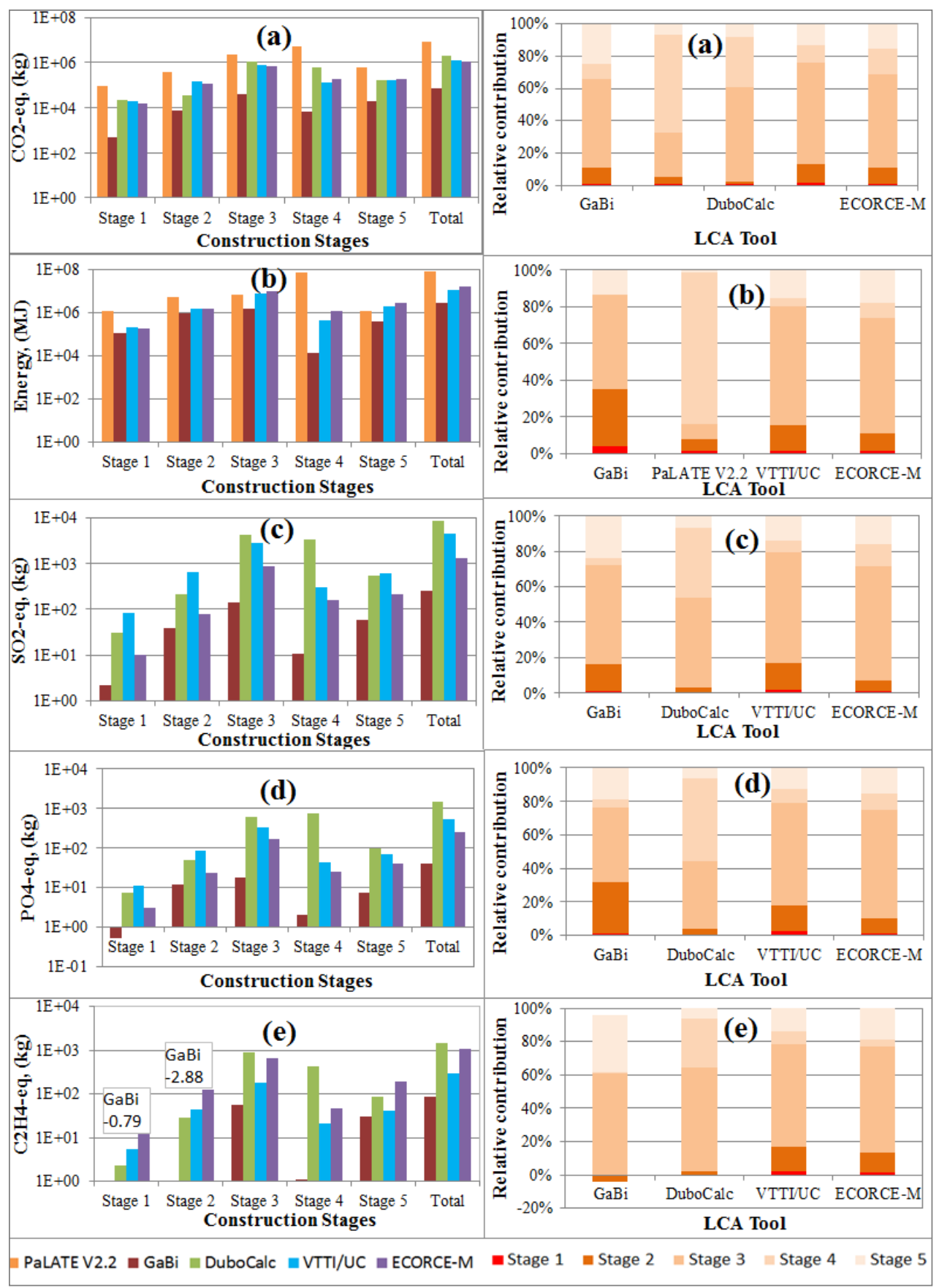

Figure 2. Comparison of the impact categories scores (left) and percentage contribution (right) from different LCA tools for the following impact categories and indicators: (a) CC; (b) energy consumption; (c) AC; (d) EU, and (e) POC.

\section{SUMMARY AND CONCLUSIONS}

The research work described in this paper investigates the extent to which the choice of an LCA tool may influence the LCA results for road pavement infrastructure. Several tools with different functionalities and geographic contexts were compared by applying them to a Spanish case study.

The results indicate that there is a considerable variability in the environmental impact scores computed with the different LCA tools for each impact category. In particular, this case study demonstrates that the impacts of the most common materials are less sensitive to the choice of the LCA tool, in contract with less-common materials. 
Based on the findings of this case study, the following recommendations can be made to improve LCA tools, the databases connect to them, and LCA practices in general: (1) there is a need for a formal consensus framework and PCR specific for pavements so that a standardized framework can be adapted to the various tools; (2) local databases of materials and processes should be developed that, for the sake of consistency, comply with national and international standards regarding technical, geographical, and temporal representativeness requirements. Those databases should be built based primarily on tight, international cooperation between academia and industry, and updated on a regular basis. The availability of such a database would improve the reliability of LCA and thereby stimulate its application; (3) the accuracy and comprehensiveness level of the datasets should be tailored to the impact category and impact assessment method; and (4) a sensitivity analysis is necessary to ascertain the uncertainty and, thus, the credibility and value of the final results.

Finally, it is important to mention that this paper focused only on the construction and maintenance phases of the pavement LCA, leaving the use phase outside of its scope as most of the tools can not include it. Therefore, it is recommended that similar studies be conducted using the use phase.

\section{REFERENCES}

Athena Sustainable Materials Institute (ASMI). 2012. Impact estimator for highways: user guide.

Bare, J. 2011. TRACI 2.0: the tool for the reduction and assessment of chemical and other environmental impacts 2.0. Clean Technologies and Environmental Policy 13: 687-696.

Blankendaal, T., Schuur, P. \& Voordijk, H. 2014. Reducing the environmental impact of concrete and asphalt: a scenario approach. Journal of Cleaner Production 66(1): 27-36.

Dauvergne, M., Jullien, A., Boussafir, Y., Tamagny, P. \& Proust, C. 2014. Logiciel ECORCE-M, version multilingues.

Environmental Product Declaration (EPD). 2013. PCR CPC 53211 highways (except elevated highways),

streets and roads.

Fernández, R. 2013. Environmental Product Declaration of “ $N-340$ ” road (Elche, Alicante). Reg. no. SEP-00516.

Fernández-Sánchez, G., Berzosa, A., Barandica, J. M., Cornejo, E. \& Serrano, J. 2015. Opportunities for GHG emissions reduction in road projects: a comparative evaluation of emissions scenarios using $\mathrm{CO}_{2}$ NSTRUCT. Journal of Cleaner Production 104: 156-167.

Glass, J., Dyer, T., Georgopoulos, C., Goodier, C., Paine, K., Parry, T., Baumann, H. \& Gluch, P. 2013. Future use of life-cycle assessment in civil engineering. Proceeding of the ICE: Construction Materials 106(4): 204-212.

Guinée, J. (ed.) 2002. Handbook on life cycle assessment: operational guide to the ISO standards. Series: eco-efficiency in industry and science. Dordrecht: Kluwer Academic Publishers.

Huang, Y., Bird, R. \& Heidrich, O. 2009. Development of a life cycle assessment tool for construction and maintenance of asphalt pavements. Journal of Cleaner Production 7: 283-296.

International Standard Organization (ISO), 2006. ISO 14025: Environmental labels and declarationsType III Environmental Declarations-Principles and procedures.

Mukherjee, A. \& Cass, D. 2012. Project emission estimator: implementation of a project-based framework for monitoring pavement greenhouse gas emissions. Transportation Research Record: Journal of the Transportation Research Board 2282: 91-99.

PaLATE v2.2 for Greenroads 2011. Software and user guide modified by Civil \& Environmental Engineering Department, University of Washington (UW).

PE International. 2012. Gabi Manual.

PRé Consultants. 2016. SimaPro Tutorial.

Rijkswaterstaat, 2015. DuboCalc version 4.01.1.

Santos, J., Ferreira, A. \& Flintsch, G. 2015a. A life cycle assessment model for pavement management: methodology and computational framework. International Journal of Pavement Engineering 16(3): 268-286.

Santos, J., Bryce, J., Flintsch, G., Ferreira, A. \& Diefenderfer, B. 2015b. A life cycle assessment of inplace recycling and conventional pavement construction and maintenance practices. Structure and Infrastructure Engineering: Maintenance, Management, Life-Cycle Design and Performance 11(9): 1199-1217.

Takano, A., Winter, S., Hughes, M. \& Linkosalmi, L. 2014. Comparison of life cycle assessment databases: a case study on building assessment. Building and Environment 79: 20-30. 